\title{
PENGEMBANGGAN MODEL PEMBELAJARAN BLENDED LEARNING BERBASIS EDMODO DALAM MEMBENTUK KEMANDIRIAN BELAJAR SISWA PADA MATA PELAJARAN EKONOMI KELAS XI IPS SMAN 1 SELONG TAHUN PELAJARAN 2017/2018
}

\author{
Muh. Fahrurrozi1 ${ }^{1}$, Muhip Abdul Majid ${ }^{2}$ \\ ${ }^{1}$ Prodi Pendidikan Ekonomi FKIP Universitas Hamzanwadi \\ email: ozyalu@gmail.com \\ ${ }^{2}$ Prodi Pendidikan Ekonomi FKIP Universitas Hamzanwadi \\ email: Majid.ekonomi@gmail.com
}

\begin{abstract}
ABSTRAK
Berdasarkan pengamatan pembeajaran di SMA Negeri 1 Selong menunjukkan adanya kendala pada pembelajaran Ekonomi Kelas XI IPS SMA Negeri 1 Selong yang disampaikan oleh guru mata pelajaran, diantaranya: kurangnya inovasi penerapan model pembelajaran yang dapat mengkonstruksikan ide-ide dan pengetahuan siswa, dan kurang tuntasnya pembahasan materi pembelajaran sehingga ada beberapa materi tertinggal. Salah satu upaya untuk mengatasi kendala tersebut adalah mengembangkan dan mengimplementasikan model blended learning berbasis Edmodo pada pembelajaran Ekonomi dengan mengkombinasikan pembelajaran tatap muka dan online. Penelitian ini bertujuan untuk merumuskan perencanaan,mengimplementasikan, dan menguji keefektifan pembelajaran dengan model blended learning pada mata pelajaran Ekonomi kelas XI IPS di SMAN 1 Selong.Metode yang digunakan dalam penelitian ini adalah Research and Development model ADDIE. Adapun populasi penelitian adalah seluruh siswakelas XI IPS SMAN 1 Selong. Sedangkan sampel penelitian adalah siswa kelasXI IPS1 dan XI IPS2 yang dipilih dengan teknik cluster sampling. Metode pengumpulan data berupa dokumentasi, observasi, tes, dan angket/kuisioner.Hasil penelitian menunjukkan bahwa (1) perencanaan pembelajaran dan Modul Praktis dengan model blended learning berbasis Edmodo layak digunakan sebagai pedoman pelaksanaan pembelajaran di kelas; (2) model pembelajaran dan modul praktis blended learning berbasis Edmodo dapat diimplementasikan sesuai perencanaan yang mencakup orientasi, organisasi, investigasi, presentasi, analisis, dan evaluasi; (3) pembelajaran dengan model blended learning berbasis Edmodo terbukti efektif dilihat dari segi (a) hasil belajar Ekonomi yang menggunakan model blended learning berbasis Edmodo $>75$ dan ada perbedaan hasil belajar yang signifikan antara kelompok yang menggunakan model blended learning berbasis Edmodo dan kelompok yang tidak menggunakan model blended learningberbasis Edmodo; (b) proses berupa peningkatan kemandirian dan motivasi belajar siswa yang lebih baik. Dari hasil penelitian ini disarankan perlunya pengembangan model blended learning berbasis Edmodo sebagai suplemen pembelajaran tatap muka pada mata pelajaran Ekonomi dan mata pelajaran yang lain.
\end{abstract}


Kata Kunci: Pengembangan, Pembelajaran, Model Blended Learning, Edmodo, Mata Pelajaran Ekonomi.

\begin{abstract}
Based on the observations of learning at SMAN 1 Selong indicate be present constraint on Economic Learning at class XI IPS of SMAN 1 Selong that is said by the subject's teacher, amongs: less of innovation learning model applications that obtains contructions the students' idea and ability, and leass complete of sstudy learning material so, there are some material left behind. One of efort to outcome the costraint are development and implementations of blended learning model base Edmodo and Economic subject with combinations the class surface learning and online. This research has a goal to formulate of planning, implementations, and verify learning effectiveness with blended learning model on Economic subject at class XI IPS of SMAN 1 Selong.The method that is used in this research are Research and Devlopment ADDIE model. Now the population of the risearch is all of the students of class XI IPS of SMAN 1 Selong. Wihile the reseach sample are the students of celass XI IPS and XI IPS 2 that is choozen by cluster sampling technique. The data collecting method are documentations, observations, test and quiz.The research result indicate that (1) the learning planinng and practical module with blended learning model base Edmodo is suitable used as orientations learning applications in the class, (2) learning implications, presentations, analysis and evaluations, organizations, investigations, presentations, analysis, and evaluations; (3) studying with blended learning evidents effective is refer to from aspects (a) Economic study result that use blended learning model base Edmodo > 75 and there is a difference result of study that significant between the group that use blended learning model base Edmodo; (b) the process in invropling self supporting and students' study motivation is better. From the research result is suggested needed the development blended learning model base Edmodo as supplement close. Surface learning o Economic subject and other subject.
\end{abstract}

Keywords: Development, Learning, Blended Learning Model, Edmodo, Economic Subject.

\title{
PENDAHULUAN
}

Terkait dengan peran guru sebagai agen pembelajaran, guru dituntut dapat memberikan pembelajaran secara optimal dengan menggunakan berbagai metode dan model pembelajaran yang disesuaikan dengan karakteristik siswa. Benny A. Pribadi (2010:18), penerapan desain sistem pembelajaran bertujuan untuk menciptakan pembelajaran yang sukses, yaitu pembelajaran yang mampu membantu siswa mencapai kompetensi yang diinginkannya. Oleh karena itu, 
pemilihan dan penerapan desain model pembelajaran menjadi salah satu faktor penentu keberhasilan penguasaan kompetensi siswa.

Salah satu kompetensi mata pelajaran yang harus dikuasai oleh siswa SMA/MA yang mengambil jurusan Ilmu Pengetahuan Sosial (IPS) yaitu mata pelajaran ekonomi. Mata pelajaran ekonomi merupakan mata pelajaran wajib bagi peserta didik yang mengambil jurusan IPS, sedangkan masih banyak para peserta didik menganggapnya sebagai mata pelajaran yang sulit dan menakutkan. Salah satu materi yang paling ditakuti oleh peserta didik pada mata pelajaran ekonomi adalah materi akuntansi dan perdagagan internasional, karna merupakan materi yang kebanyakan peserta didik menganggapnya materi yang membosankan. Oleh karena itu desain model dan strategi yang digunakan harus menyenagkan dan mampu mengembangkan teknologi guna pengembangan kompetensi kemandirian dan pengalaman belajar siswa secara teori maupun praktik.

Berdasarkan hasil observasi dan interview pada saat awal peneliti melaksanakan Magang III di SMAN 1 Selong, pembelajaran yang biasa diterapkan oleh guru Mata Pelajaran Ekonomi selama ini menggunakan metode ekspositoris dilakukan secara tatap muka di dalam kelas dengan dukungan sarana dan perasarana yang memadai, di mana pembelajaran berpusat pada guru, siswa pasif, dan kurang terlibat dalam pembelajaran. Namun, pemanfaatan dan pengembangan sarana dan perasarana tersebut belum optimal. Hal ini menyebabkan siswa mengalami kejenuhan yang berakibat kurangnya minat dan kemandirian belajar. Minat dan kemandirian belajar akan tumbuh dan terpelihara apabila kegiatan belajar mengajar dilaksanakan secara bervariasi, baik melalui variasi model maupun media pembelajaran secara interaktif. Untuk itu diperlukan strategi belajar baru yang lebih memperdayakan siswa.

Selain dari pada itu, saat peneliti mengajar di kelas XI IPS SMAN 1 Selong dijam terakhir pelajaran, banyak siswa yang tidak memperhatikan dan ada juga yang tidur terutama yang duduk dibangku bagian belakang. Sehingga materi yang disampaikan sulit dipahami dan dimengerti oleh siswa tersebut. Berkenaan dengan itu, perlu adanya model pembelajaran yang dapat membantu peserta didik dalam menigkatkan kemandirian dan kompetensi belajarnya. 
Salah satu model pembelajaran adalah blended learning berbasis edmodo. M.Yusuf T. (2011) mendefinisikan blended learning sebagai integrasi antara face to face dan online learning untuk membantu pengalaman kelas dengan mengembangkan teknologi informasi dan komunikasi. Thorne (2003: 2) dalam Sulihin B. Sjukur (2012) mendefinisikan blended learning sebagai berikut.

"it represents an opportunity to integrate the innovative and technological advances offered by online learning with the interaction and participation offered in the best of traditional learnin".

Definisi di atas mengandung makna bahwa blended learning menggambarkan sebuah kesempatan yang mengintegrasikan inovasi dan keuntungan teknologi pada pembelajaran online dengan interaksi dan partisipasi dari keuntungan pembelajaran tatap muka. Sementara itu, Uwes A. Chaeruman (2011) menjelaskan blended learning sebagai pembelajaran yang mengkombinasikan setting pembelajaran synchronous dan asynchronous secar tepat guna untuk mencapai tujuan pembelajaran. Beberapa definisi di atas, memberikan gambaran bahwa blended learning merupakan kombinasi antara pembelajaran tatap muka dan pembelajaran online dengan bantuan teknologi informasi dan komunikasi secara tepat guna untuk mencapai tujuan pembelajaran.

Adapun untuk dapat menerapkan model blended learning berbasis Edmododalam pembelajaran tentu diperlukan perencanaan terlebih dahulu yang disesuaikan dengan kebutuhan dan karakteristik siswa. Berdasarkan uraian di atas, diperlukan pembelajaran dengan model blended learning berbasis edmodo, khususnya pada mata pelajaran Ekonomi. Oleh karena itu, peneliti tertarik untuk mengadakan penelitian tentang "Pengembangan Model Pembelajaran Blended Learning Berbasis Edmodo Dalam Membentuk Kemandirian Belajar Siswa Kelas XI IPS SMAN 1 Selong Tahun Pelajaran 2017/2018”.

\section{METODE PENELITIAN}

Pengembangan model pembelajaran Blended Learning berbasis Edmodo ini menggunakan metode penelitian dan pengembangan (research anddevelopment). Menurut Sugiyono (2011: 297) penelitian dan pengembangan 
merupakan metode penelitian dengan tujuan untuk menghasilkan produk tertentu, dan menguji keefektifan produk tersebut. Pendapat lain diungkapkan oleh Endang Mulyatiningsih (2011: 161) yaitu "penelitian dan pengembangan bertujuan untuk menghasilkan produk baru melalui proses pengembangan". Secara umum, penelitian dan pengembangan merupakan penelitian yang bertujuan untuk menghasilkan produk baru dan menguji keefektifan produk tersebut.

Prosedur penelitian ini mengadaptasi model pengembangan ADDIE, yaitu model pengembangan yang terdiri dari lima tahapan yang terdiri dari Analysis (analisis), Design (desain), Development (pengembangan), Adapun desain penelitian ini terbagi ke dalam 3 bagian, yaitu desain penelitian perencanaan, moduk praktis siswa, implementasi, dan keefektifan model pembelajaran blended learning berbasis Edmodo.

\section{HASIL DAN PEMBAHASAN}

Bukti Pengamatan Pembelajaran dengan Model Blended Learning dan ModelKonvensional Tanggal 19 Juni - 17 Juli 2017

\begin{tabular}{|c|c|c|c|c|}
\hline \multirow[b]{2}{*}{ Aspek } & \multicolumn{2}{|c|}{ Antusias } & \multicolumn{2}{|c|}{ Bukti } \\
\hline & \begin{tabular}{l}
\multicolumn{2}{l}{ Pembelajaran } \\
Model Blended \\
Learning \\
Edmorbasis \\
\end{tabular} & $\begin{array}{l}\text { Pembelajaran } \\
\text { Konvensional }\end{array}$ & $\begin{array}{l}\text { Pembelajaran } \\
\text { Model Blended } \\
\text { Learning } \\
\text { Berbasis Edmodo }\end{array}$ & $\begin{array}{l}\text { Pembelajaran } \\
\text { Konvensional }\end{array}$ \\
\hline $\begin{array}{l}\text { Suasana } \\
\text { pembelajar } \\
\text { a } \\
\text { dan } \\
\text { kegiatan } \\
\text { awal } \\
\text { pembelajar } \\
\text { an }\end{array}$ & $\begin{array}{l}\text { Guru } \\
\text { mempersiapkan } \\
\text { pembelajaran } \\
\text { dan siswa } \\
\text { antusias untuk } \\
\text { membuka } \\
\text { modul praktis yang } \\
\text { sudah ada pada } \\
\text { aplikasi Edmodo }\end{array}$ & $\begin{array}{l}\text { Siswa kurang } \\
\text { antusias saat } \\
\text { persiapan awal } \\
\text { pembelajaran }\end{array}$ & & 25 \\
\hline
\end{tabular}




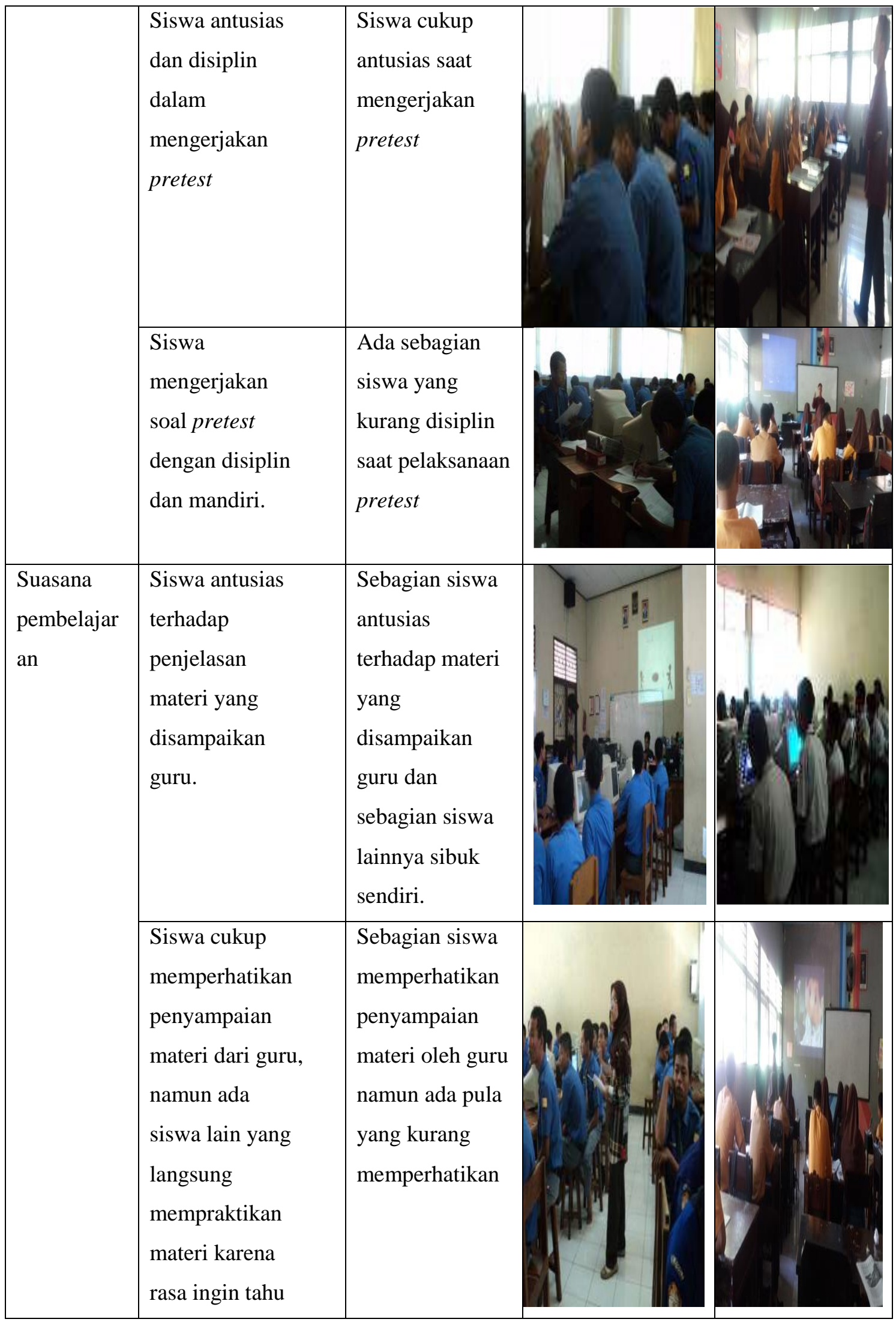




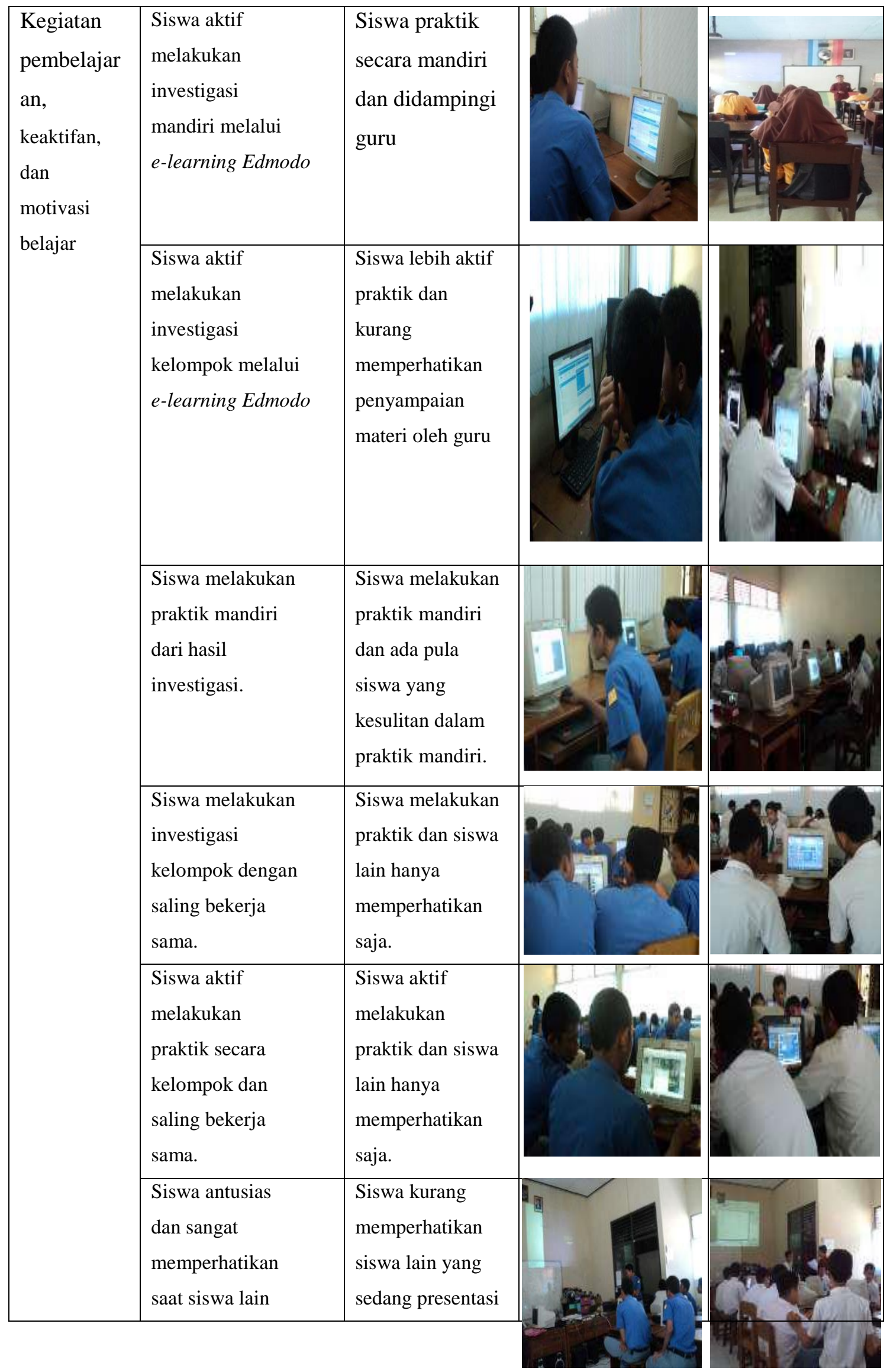




\begin{tabular}{|l|l|l|l|}
\hline $\begin{array}{l}\text { sedang presentasi } \\
\text { di depan kelas. }\end{array}$ & di depan kelas \\
\hline $\begin{array}{l}\text { Antusiasme siswa } \\
\text { saat } \\
\text { memperhatikan } \\
\text { siswa lain yang } \\
\text { sedang presentasi } \\
\text { dan siswa tampak } \\
\text { sangat } \\
\text { termotivasi. }\end{array}$ & $\begin{array}{l}\text { Siswa kurang } \\
\text { memperhatikan } \\
\text { saat siswa lain } \\
\text { sedang presentasi } \\
\text { di depan kelas dan } \\
\text { kurang } \\
\text { termotivasi. } \\
\text { Siswa tampak } \\
\text { antusias dalam } \\
\text { mengerjakan } \\
\text { posttest dengan } \\
\text { disiplin. }\end{array}$ & $\begin{array}{l}\text { Siswa tampak } \\
\text { kurang antusias } \\
\text { dalam } \\
\text { mengerjakan } \\
\text { posttest dengan } \\
\text { kurang disiplin } \\
\text { dan kurang } \\
\text { bersemangat. }\end{array}$ \\
\hline
\end{tabular}

Berdasarkan hasil pengamatan implementasi pembelajaran Ekonomi kelas XI IPS di atas, menunjukkan bahwa pembelajaran dengan model blended learning berbasis Edmodo mampu meningkatkan antusias siswa dalam kegiatan pembelajaran. Siswa tampak lebih antusias, semangat, termotivasi, dan disiplin dalam mengikuti pembelajaran. Hal ini menunjukkan pembelajaran dengan model blended learning berbasis Edmodo mampu memberikan pengalaman belajar yang lebih tinggi dibandingkan dengan model konvensional. Pada pembelajaran konvensional, sebagian siswa tampak lebih sibuk sendiri selama proses pembelajaran berlangsung.

Pembelajaran dengan model blended learning berhasil dilaksanakan dengan baik dilihat dari hasil belajar siswa pada kelompok eksperimen yang mencapai Kriteria Ketuntasan Minimal (KKM), dengan nilai lebih dari 75. Hal ini sesuai dengan teori Nana Sudjana (2009: 37) yang menyatakan bahwa proses pengajaran yang optimal memungkinkan hasil belajar yang optimal pula. Oleh karena itu, pembelajaran dengan model blended learning berbasis Edmodo 
mampu menciptakan kondisi pembelajaran yang kondusif sehingga mampu memberikan hasil pembelajaran yang optimal.

Adapun berdasarkan hasil belajar siswa pada Ulangan Harian 1 dan Ulangan Harian 2 sebagaimana tertera pada tabel 4.25 halaman 153, menunjukkan bahwa ada perbedaan antara hasil belajar kelompok yang menggunakan model blended learning dengan kelompok yang tidak menggunakan model blended learning dalam pembelajaran Ekonomi. Hal ini dilihat dari nilai $t_{\text {hitung }}>t_{\text {tabel }}$. Dimana pada posttest $\mathrm{UH} 1$ sebesar 2,228 dan $t_{\text {hitung }}$ posttest $\mathrm{UH} 2$ sebesar 4,541 serta $t_{\text {tabel }}$ sebesar 1,47 .

Sedangkan dari nilai rata-rata kelompok eksperimen pada posttest UH 1 sebesar 82,63 dan 85,13 pada posttest UH 2. Sementara itu, pada kelompok kontrol mendapat rata-rata pada posttest UH 1 sebesar 79,87 dan 78,95 pada posttest UH 2. Dari hasil perbedaan nilai rata-rata kelompok yang menggunakan model blended learning berbasis Edmodo dan kelompok yang tidak menggunakan model blendedlearning berbasis Edmodo, dapat disimpulkan bahwa pembelajaran dengan model blended learning berbasis Edmodo dapat menawarkan satu level lebih tinggi daripada pengalaman pada pembelajarantatap muka sebagaimana teori dari Dziuban, Hartman, dan Moskal (2004: 3).

Meninjau dari hasil tabel 4.37 menunjukkan bahwa pembelajaran Ekonomi dengan model blended learning berbasis Edmodo telah dilaksanakan dengan sangat baik. Hal ini terlihat dari bagan kemandirian dan motivasi belajar siswa yang mengalami peningkatan dari pertemuan 3-4 hingga 5-6.

Adapun kemandirian belajar siswa yang termasuk kategori sangat baik yaitu sebesar $85,3 \%$ pada pertemuan 3-4 dan 87,4\% pada pertemuan 5-6 menggambarkan keefektifan pembelajaran, yaitu siswa selalu aktif dalam kegiatan fisik berupa bertanya, mengerjakan tugas, menanggapi pertanyaan, menjawab pertanyaan, berlatih keterampilan, serta kegiatan psikis berupa memecahkan masalah, membandingkan konsep, dan menyimpulkan hasil percobaan sebagaimana teori Dimyati dan Mudjiono (2009: 45). Keaktifan belajar siswa dalam kegiatan pembelajaran baik secara fisik maupun psikis menunjukkan 
bahwa siswa terlibat aktif pada aktivitas belajar. Dalam hal ini, siswa merasa senang dan selalu ingin tahu untuk terlibat aktif dalam aktivitas pembelajaran.

\section{KESIMPULAN}

Berdasarkan hasil penelitian dan pembahasan yang telah dilakukan, maka dapat ditarik kesimpulan sebagai berikut:

1. Perencanaan pembelajaran dan modul praktis Ekonomi dengan model blended learning berbasis Edmodo padamateri Pendapatan Nasional layakdigunakan sebagai pedoman dalam pelaksanaan pembelajaran. Ditinjau daridasar pertimbangan pemilihan model pembelajaran blended learningberbasis Edmodo,menunjukkan tujuan yang hendak dicapai, materi pembelajaran, sudutpandang siswa, efektivitas dan efisiensi sesuai dengan konten pembelajaran Ekonomi. Ditinjau dari komponen sistem pembelajaran menunjukkan tujuan,materi, metode, media, dan evaluasi model blended learning sesuai denganpokok bahasan materi pembelajaran Ekonomi. Dari komponen perangkatpembelajaran dan modul praktis siswa model blended learning berbasis Edmodo menunjukkan adanya identitas matapelajaran, SK, KD, indikator, tujuan, alokasi waktu, metode, kegiatanpembelajaran, penilaian, dan sumber belajar yang sesuai dengan komponen perangkat pembelajaran Ekonomi.Dari kunci model blended learningberbasis Edmodo menunjukkan adanya live event, self paced learning, collaboration,assesment, and performance support learning yang sesuai dengan materi dan kegiatan pembelajaran Ekonomi;

2. Model pembelajaran blended learning berbasis Edmodo dapat diimplementasikan sesuai perencanaan pembelajaran yang mencakup: orientasi, organisasi, investigasi, presentasi, analisis, dan evaluasi serta mengkombinasikan setting pembelajaran synchronous dan asynchronous. Adapun implementasi model pembelajaran blended learning berbasis Edmodo sesuai dengan proportion of content delivered online tipe kelas blended/hybrid dengan adanya kombinasi pembelajaran tatap muka dan online pada rentang antara 30-79\%. Implementasi model pembelajaran 
blended learning dapat digunakan sebagai suplemen kegiatan pembelajaran tatap muka dengan adanya akses belajar secara online, menuntaskan penyampaian materi dalam cakupan yang luas dengan kompetensi teori maupun praktik, dan adanya kombinasi pembelajaran tatap muka dan online yang tersistematis sehingga mampu membangun pengkonstruksian ide-ide siswa;

3. Pembelajaran dengan model blended learning berbasis Edmodo terbukti efektif ditinjau dari segi: (a) hasil belajar Ekonomi yang menggunakan model blended learning berbasis Edmodo >75 dan ada perbedaan hasil belajar yang signifikan antara kelompok yang menggunakan model blended learning berbasis Edmodo dan kelompok yang tidak menggunakan model blended learning berbasis Edmodo; (b) proses berupa peningkatan kemandirian dan motivasi belajar siswa yang lebih baik.

\section{DAFTAR RUJUKAN}

Allen, IE, Seamen, J. \& Garret, R. 2007. Blending in: The Extent andPromise ofBlended Education in the United States. USA: TheSloan Consortium.

Arend, R.I. 2008. Learning to Teach. New York: McGraw HillCompanies.

Arikunto, Suharsimi. 2002. Prosedur Penelitian Suatu PendekatanPraktek.Jakarta: Rineka Cipta.

Peribadi A. Benny. 2009. Model Desain Sistem Pembelajaran.Jakarta: Dian Rakyat.

Perihadi Singgih. 2013. Model Blended Learning. Surakarta: YumaPustaka.

Priowirjanto, Gatot. 2013. Tutorial SEA EduNet 2.0. Jakarta:Seamolec.

Sukwiaty, dkk. 2006. Ekonomi. Jakarta. PT Ghalia Indonesia Printing.

Sugiyono. 2010. Metode Penelitian Pendidikan Pendekatan Kualitatif, Kuantitatif, dan $R \&$ D. Bandung: Alfabeta. 